\title{
Милош ЈОЦИТ
}

\author{
ШТА ЈЕ ИГРАО ПАВИЋ? \\ О лудолошко-наративним аспектима
}

Филозофски факултет, Нови Сад

Апстракт: Овај рад се бави проучавањем есеја „Романи без речи“ Милорада Павића, једним од првих покушаја лудолошко-наративне анализе видео-игара у српској књижевној науци. У овом есеју Милорад Павић је пружио јединствено сведочанство о савременој хипертекстуалној и хипермедијској књижевности, а нарочито значајан је његов осврт на четири авантуристичке видео-игре: Myst, Myst 2: Riven, Zork: Nemesis и Timelapse. Анализирајући историјски развој жанра авантуристичких игара, њихову хипертекстуалну архитектуру, мотивски склоп, технолошке карактеристике, као и елементе фантастике које их повезују са поетиком постмодернистичке прозе, покушаћемо да објаснимо механизме Павићевих лудолошко-наративних коментара, односно дубинске поетичке разлоге који стоје иза његовог избора управо ових остварења за демонстрирање литерарно-уметничке вредности видео-игара.

Кључне речи: Милорад Павић, Романи без речи, интерактивна фикција, хипертекст, видео-игре, лексија

Можда ће данашњи нови талас нелинеарног приповедања спасити књижевност од нашег у линеарни шаблон сатераног језика, и тога не би требало да се плашимо. Можда смо на прагу разарања реченице, која је творница линеарности и алатка за шкопљење људске мисли. Можда.

Милорад Павић, „Кратка историја читања“

\section{1. Романи без речи: Павићеви погледи на савремену хипертекстуалну књижевност}

Француски критичар Филип Третијак (Phillipe Tretiak) сигурно није знао колико ће један његов илустративни цитат постати општепопуларан, канонски и антологијски у једној другој књижевности. Његов опис Хазарскої речника Милорада Павића као „прве књиге

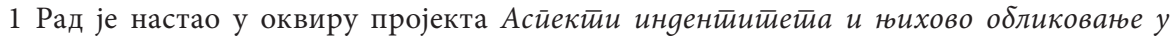
срйској књижевносиии (178005) Одсека за српску књижевност и језик Филозофског факултета у Новом Саду. Координатор пројекта је проф. др Горана Раичевић. 
21. века“, изречен у приказу романа у Paris Match-у $1988 .{ }^{2}$ данас је вероватно један од најрабљенијих блурбова у српској књижевности уопште; цитат афористичне сажетости, небројено пута преношен и коришћен како у популарној култури тако и у књижевној науци на изванредан начин описује не само Павићев роман-лексикон него и читаво пишчево хипертекстуално стваралаштво. Павић је, наравно, и у каснијим годинама и деценијама био предмет проучавања савремене хипертекстуалне наратологије. Његова дела нашла су место у макар две значајне студије о ергодичкој књижевности, односно нелинеарној/хипертекстуалној фикцији: у капиталној студији Cybertext Еспена Арсета (Aarseth), делу које се након Ойвореноі gела Умберта Ека најдетаљније бавило изучавањем овакве врсте књижевности, али овога пута укључујући и нове, дигиталне књижевне медијуме попут интерактивне фикције и видео-игара; и у истраживању Narrative as Virtual Reality Мери-Лор Рајан (Marie-Laure Ryan), које се бавило феноменом виртуелне уметности како на примеру „традиционалне“, тако и компјутерске књижевности.

О Павићу као хипертекстуалном писцу сигурно не мањка студија, критика и наратолошких истраживања. Најскорије међу њима, Поетиика форме у йрози срйској йосймодернизма (2013) Але Татаренко, објављено је пре непуних шест година. Међутим, ниједно од ових проучавања није у обзир узимало Павићеве ауторске записе о овој врсти савремене књижевне продукције. Захваљујући томе што су ови огледи написани са извесне историјске удаљености, односно неколико година, па и деценију након што је Павић написао своја најпознатија ергодичка дела попут Хазарскої речника или Преgела сликаноі чајем, ти текстови нам указују да хипертекстуални рад овог аутора није било производ искључиво индивидуалистичке луцидности, или пак само последица реимагинације одређених барокних књижевних форми попут лавиринтске песме, carmen labyrinthicum, нелинеарног визуелног лирског облика. Напротив: Милорад Павић, у српској књижевној науци познат као историчар старије српске књижевности, током свог каснијег стваралаштва наставио је да се активно упознаје са појавама из ове врсте књижевности, пратећи притом чак и нове технолошке и мултимедијалне трендове у свету рачунарства и информатике.

Текстови о којима говоримо писани су, објављивани и казивани углавном током деведесетих година прошлог века, а обједињени су у издању Роман као gржава и gруїи оїлеgи (Плато, 2005), прецизније у два циклуса - „Роман као држава“ и „Књига у новоме миленијуму“ - који се баве, у подједнакој мери, и положајем традиционалне, „папирне“ књиге на истеку другог миленијума и њене будућности

2 Phillipe Tretiak, „Enfin un roman qu’on peut lire danas tous les sens“. Paris Match, 17. marta 1988. 
у новим, дигитализованим форматима. У есеју „Гатање као компјутерска игра“ Милорад Павић отворено и поетички свесно говори о лудолошком аспекту својих дела - тачније, о Послеgюој љубави у Цариіраgy, за коју је пружио концепт њене интерактивне, дигитализоване адаптације у којој би се дело читало са монитора, и где би читалац мишем кликтао на наслове поглавља, ликове тарот карата, наређивао рачунару да меша карте или извршава различита тарот отварања (Павић 2005: 27). Овом приликом је Павић описао претварање једносмерног текста књиге у хипермедијално - што ће рећи хипертекстуално и мултимедијално - окружење, чијим би се елементима читалац/играч слободно играо, односно које би истраживао на начине који нису омеђени линеарним током наратива.

Оглед „Неколико речи о умору и позоришту које умире већ више од три хиљаде година“ такође је сведочење о ауторовој свести о стваралачким могућностима које леже у књижевностима нових медија. Значајно је у том смислу његово подсећање на две, како их је сам

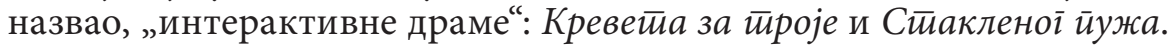
Павић овом приликом подвлачи да је потоње дело адаптирано од истоимене приче која је изворно „писана за Интернет и публикована најпре на мрежи“ (Павић 2005: 35), то јест да је изворна приповетка концептуално, од зачетка, намењена објављивању на нелинеарном, дигиталном окружењу хиперлинковане светске мреже, уместо на традиционалном медијуму папира. Још један есеј, „Књига у новом миленијуму“, додатно развија мисао о томе како древни уметнички медијум попут књижевности (или позоришта) увек налази начина да себе освежи, макар у формалном смислу, као и да електронска књига ни у ком случају није смрт књиге него њена ревитализација у новом медијуму („Дакле, књига ће опстати у новом миленијуму. У овом или оном облику, што уосталом, све више води ка истом“; Павић 2005: 56) - на исти начин, можемо овом приликом додати, као што је кодекс представљао нову врсту медијума писане речи у односу на свитке, и као што је штампани текст представљао крај рукописних књига. Поред електронских читача, Павић се у овом есеју дотиче и појаве компјутерске поезије, тачније „песничке машине“ немачког песника Ханса Магнуса Енсенсбергера (Enzensberger). У питању је жанр који је у сваком смислу другачији од интерактивне фикције, чије се комбинаторичке игре обично заснивају на принципима насумичности, а не читаочевој свесној манипулацији, често у правцу језичке самореферентности или деструкције значења - што показује колико је жанр дигиталне књижевности већ тада, у Павићевом запажању, био богат различитим облицима и идејно супротним поджанровима.

Нарочито значајан текст у овом избору, и онај који ће бити тема овог истраживања, јесте „Романи без речи“, технофутуролошко излагање Милорада Павића на отварању научног скупа „Информаци- 
оне технологије: садашњост и будућност“, који су 1998. године организовали Електротехнички факултет Универзитета у Београду и Електротехнички факултет Универзитета у Црној Гори. За разлику од претходно поменутих огледа, који су се одреда бавили пишчевим коментарима сопствених текстова и уопштенијих особености хиперфикције, Павић се овом приликом осврнуо на неколико значајних светских аутора и дела из области интерактивне књижевности. Павић се на овом месту тако окренуо значајном чланку Роберта Кувера (Coover) „The End of Books“ објављеном у Њујорк йајмсу 1992. године ${ }^{3}$. Куверов чланак је попут поменутих Павићевих текстова говорио о будућности папирне књиге пред појавом нових медија и нових технолошких феномена; односно, како је сам Кувер записао, о крају романа у свету „видео-преноса, мобилних телефона, факс машина, рачунарских мрежа, [...] дигиталних округа авангардних компјутерских хакера, киберпанкера и хајперспејс фрикова“ .

Међутим, окосницу Куверовог текста представља поглед на хипертекстуалну фикцију као нови књижевни облик. За самог Павића је овај чланак био додатно релевантан услед чињенице да га је професор Кувер уврстио у ону групу аутора која је „и пре рођења компјутерског романа“ (Павић 2005: 60) његову појаву антиципирала; ту династију чинили су, поред Милорада Павића, најрелевантнији прозни експериментатори европске и светске традиције: Сервантес, Лоренс Стерн, Џејмс Џојс, Рејмон Кено, Хулио Кортасар и Итало Калвино. Уз коментарисање Куверовог чланка, Павић се у овом излагању дотакао и теорије „отвореног дела“ Умберта Ека, као и примера Мајкла Џојса (Michael Joyce), аутора првог компјутерског романа Afternoon, који је 1987. године био издат на флопи-диску, као што је сам Павић интерактивну приповетку „Стаклени пуж“ такође наменио објављивању на нетрадиционалном, негутенберговском медијуму интернета. Попут Павића, и Џојс је превазишао оквире експерименталне књижевности и постао део канона постмодерне литературе. Тумачењу романа Afternoon посвећена су поглавља у готово свим релевантним студијама о хипертекстуалној/ергодичкој књижевности (Арсет, Рајан, Џорџ Лендоу / George Landow), а одломак из романа заступљен је и у Postmodern American Ficton: A Norton Anthology.

Није потребно додатно објашњавати зашто Павић спомиње Куверов чланак, Екову наратолошко-семиотичку теорију и Џојсово дело. Први случај је, будући објављен у Њујорк йајмсу, био један од првих

3 Милорад Павић погрешно смешта овај чланак у 1988. годину, помешавши га вероватно са приказом Хазарскоі речника који је Роберт Кувер, под насловом „Не Thinks The Way We Dream“, управо 1988. објавио такође у Њујорк йајмсу.

4 http://movies2.nytimes.com/books/98/09/27/specials/coover-end.html, приступљено 17. фебруара 2019.

5 http://www.wwnorton.com/college/english/pmaf/pmaftoc.htm, приступљено: 17. фебруара 2019. 
текстова који је широј читалачкој публици указивао на литерарне могућности које је доносила форма дигиталног хипертекста; други случај представљао је, у то време, не само најрелевантнију него и једину научну студију о интерактивној уметности, која је притом већ три године по објављивању на италијанском била преведена на српскохрватски (1965, ИП „Веселин Маслеша“, преводилац Ника Милићевић); трећи je, већ тада, као први аутор „компјутерског романа“, био добро познат и изучаван куриозитет постмодернистичке технокултуре.

Помињање ових аутора представља тек неку врсту контекстуалног увода за онај део Павићевог излагања који се тиче осврта на титуларне „романе без речи“, односно следеће видео-игре: Myst, Myst 2: Riven, Zork: Nemesis и Timelapse. Павићева похвала ових „романа без речи“, које описује као „домен hyperfiction стваралаштва [који нас] одводи у креацију која напушта језик и улази у мултимедијалне просторе“ (Павић 2005: 61), иако кратка и намењена пригодном усменом излагању на некњижевним научном симпозијуму, представља вероватно први озбиљнији покушај - свакако први аутора и књижевног научника Павићеве репутације - лудолошко-наративног тумачења видео-игара у српској књижевности, то јест првог случаја признавања литерарне вредности видео-играма.

„Романе без речи“ Павић додатно описује као дела објављена на CD-ROM-y која су „нека врста савршено дизајнираног авантуристичког филма, али се разликују од филма у оном истом домену у којем се класични роман разликује од интерактивног романа“ (Павић 2005: 61) и која се такође од „компјутерских игрица“ одвајају „својом тематиком за одрасле, сложеношћу, изванредним визуелним и звучним ефектима који понекад превазилазе све виђено на филму, и пре свега својом интерактивношћу“ (Павић 2005: 62). Упркос томе што Милорад Павић признаје књижевно-уметничку вредност овим насловима тек након што их раздвоји од пежоративног деминутива „игрице“, сва поменута остварења несумњиво јесу видео-игре, и то релативно популарне у време је Павић писао овај есеј: Myst не само да се крајем деведесетих година могао играти на готово свакој постојећој платформи, од различитих модела кућних рачунара (PC, Macintosh, Amiga) до ТВ конзола (Playstation, Sega Saturn, Atari Jaguar $\mathrm{CD}, \mathrm{CD}-\mathrm{i})$, него је био и најпродаванија видео-игра у историји, што је титула коју је ово дело изгубило тек 2002. године, објављивањем револуционарне симулације приватног живота The Sims. У наставку рада ћемо покушати да пружимо детаљни одговор на питање зашто је Павић одабрао баш поменута дела као примере уметничке вредности видео-игара. Одговори на ова питања ће нам пружити вредне увиде не само у њихове одређене књижевно-уметничке елементе, које су постмодерног фантастичног писца попут Павића могле навести да их спомене, него и ближи увид у веома специфичну архитектуру хипертекстуалне прозе овог аутора. 


\section{2. Игре које се читају: авантуристички жанр}

Део одговора на питање зашто је Павић у свом тексту скренуо пажњу на баш поменута четири наслова - Myst (1993), Riven (1997), Zork: Nemesis (1996) и Timelapse (1996) - можемо пронаћи у заједничком скупу њихових заједничких стилских, мотивских и механичких особина. Већ на самом почетку, овај пресек показује неколицину очигледних сличности између „поетике“ ових видео-игара и добро изучених прозних карактеристика стваралаштва Милорада Павића:

a) Све набројане видео-игре поседују снажне елементе фантастике. Zork: Nemesis у потпуности се одвија у измаштаном, нереалном свету; Timelapse, где окосницу радње чини потрага главног јунака за Атлантидом, јесте дело у којем играч помоћу времеплова путује у доба египатске, мајанске и Анасазија цивилизације (северноамеричког домородачког народа); у Myst-y и његовом наставку, Riven-y, играч се из стварног света пребацује у неколико различитих фантазијских светова, од којих су они названи „Мист“ и „Ривен“ главне позорнице радње.

б) Све поменуте видео-игре истоветне су у визуелном и механичком смислу. Игривост, односно gameplay, у њима се одвија из перспективе првог лица (first person), што значи да играч, за разлику од игара у трећем лицу, односно оних које се играју из изометријске перспективе, овде никада заправо не види свог јунака/аватара него свет дословно посматра из његових очију. Даље, будући да су графичку репрезентацију виртуелног простора у овим играма чинили статични екрани чије је смењивање симулирало дубину и отвореност тродимензионалног простора, ове игре су за своје време поседовале готово фотографски реалистичну и детаљну графику. ${ }^{6}$ Сам Павић је као главне особине ових игара издвојио њихове „изванредне визуелне и звучне ефекте“, који су, уз играње из првог лица, чинили да ове видео- игре више него било које књижевно или уметничког дело до тада дочарају имерзију у виртуелни свет фиктивног дела.

в) Све споменуте игре припадају истом жанру видео-игара: такозваном „авантуристичком“ жанру.

Задржаћемо се на последњој линији сличности како бисмо поближе објаснили значај ове жанровске повезаности за лудо-

6 У време када су ове игре објављене, што ће рећи од почетка до средине деведесетих година, приказивање отвореног ЗД простора у видео играма и даље је било технолошки захтевно и још није заживело као стандард у индустрији видео-игара. Најпознатији примери раних тродимензионалних компјутерских игара, пуцачине из првог лица Wolfenstein 3D (1991) и Doom (1993), заправо су користили комбинацију ЗД мапирања и $2 Д$ простора, стварајући вешту илузију тродимензионалног кретања. Павићеви „романи без речи“ такође су користили сличне трикове. Због тога што су уместо правог, отвореног ЗД простора користили само статичне слике, ресурси рачунара и кућних конзола могли су да се усмере у што боље приказивања рендероване 2Д топографије, што је овим играма пружало, за оно време, веома детаљну графику. 
лошко-наративно тумачење ових дела. У авантуристичком жанру видео-игара играч истражује нелинеарни простор по којем се, у одређеним границама, може кретати по сопственом нахођењу. Интеракција коју врши са виртуелним светом углавном је ненасилна; изазов у авантуристичким играма чини сакупљање предмета, њихова правилна комбинација и употреба, и решавање логичких загонетки - а не уништавање противника и сл. Пред играча се на почетку игре поставља одређена мистерија, попут решавања убиства или проналаска нестале особе или предмета, чије разрешење посредством истраживања света и интеракције са околином постаје главни циљ игре. На пример, у игри Zork: Nemesis циљ играча је решавање убиства; у Myst-y је то потрага за творцем необичног света у којем смо ce нашли; у Timelaps-y задатак је откривање судбине изгубљене цивилизације. Другим речима, авантуристичке игре карактерише присуство изграђене наративне димензије, као што и сам Милорад Павић запажа назвавшви их „романима“ и поредећи их са авантуристичком фикцијом, односно делима популарне књижевности која обично поседују сложене заплете (чији бројни обрти, односно перипетије, представљају главни извор читалачког уживања).

У архетипској подели игара Криса Крофорда (Chris Crawford) из 1982. године, уједно и првом покушају генологије овог медијума, игре су подељене на две врсте. Како ово представља фундаменталну поделу игара на основу њихове игривости, односно њихових лудолошких особености, ово раздвајање можемо сматрати комплементарним књижевној подели на родове. Према Крофордовој „таксономији“, како ју је аутор назвао (Crawford 1997: 21), основна честица разлике између различитих облика компјутерских игара јесте интеракција, односно изазов: игра пред играча поставља одређене изазове које он мора превазићи како би прешао или победио игру, а различити типови тих изазова (и начини њиховог превазилажења) главни су критеријум при одређивању рода, облика и жанра видео-игара.

Прва група видео-игара у Крофордовој подели тако су „игре вештине и акције“ (skill-and-action games), у које спадају жанрови борбених игара, спортских и тркачких симулација, као и одређени аркадни жанрови који, иако део Крофордовог образложења, данас готово да и не постоје (maze games - итеракције Pac Mana; paddle games - деривати Arkanoida). Изазов у овим играма подразумева директну, често и насилну конфронтацију са препрекама које неретко долазе у облику непријатеља који се мора уништити или на неки други начин савладати. Овакве игре захтевају од играча тренутну реакцију и спретно управљање контролором (џојстиком, џојпедом, тастатуром или мишем); успех у игри зависи искључиво од играчеве агилности, то јест од брзине и прецизности његових реакција. Крофорд коментарише да већина видео-игара припада овој групи и да већина људи видео-игре повезује искључиво са насловима који 
припадају овом роду (Crawford 1997: 21). Можемо запазити да овај коментар важи и данас, па тако и у првим деценијама 21. века најпопуларнији, најутицајнији и најисплативији жанрови видео-игара припадају играма вештине и акције.

Други род видео-игара чине тзв. стратегијске игре (strategy games). За разлику од претходне групе, стратегијске игре више теже „когитацији него манипулацији“ (Crawford 1997: 29). Њихови изазови су когнитивни, а не механички, и пред играча представљају препреке које захтевају планирање и дугорочно размишљање уместо тренутних рефлексних реакција. Препреке се у овим играма не базирају на елиминацији противника него на решавању загонетки, сналажењу у различитим дијалошким опцијама, навигацији у комплексном виртуалном простору и управљању ресурсима и разним облицима статистичких података, попут нумерички изражених особина и вештина аватара/јунака, које се нпр. у играма играња улога (role playing games, RPG) временом увећавају, те њихово уређивање у сврху максимализације успеха постаје све сложенији задатак. Уз игре играња улога, најрепрезентативнији представници овог лудолошког рода јесу авантуристичке игре, којима припадају и Павићеви „романи без речи“.

Разлог зашто су авантуристичке игре од самих својих зачетака (прве авантуристичке компјутерске игре направљене су још крајем седамдесетих година прошлог века) поседовале изражену и за медијум видео-игара прилично комплексну наративну димензију - нарочито у поређењу са акционим играма - можемо пронаћи у чињеници да су изазови, препреке и интеракције у овим играма пре свега менталне, а не акционе, па су стога сличне церебралном напору који је потребан за читање и разумевање текста, за разлику од игара акције и вештине које су се бавиле симулацијом динамичних акција попут пуцања из оружја, летења авионом или играњем спорта. Арсет је упоређивао труд потребан за довршавање авантуристичке игре са оним који је потребан да се чита и прочита комплексан роман (Aarseth 1997: 113); Арсет спомиње и наводе из дисертације о интерактивној фикцији ${ }^{7}$ Мери Ен Баклс (Mary Ann Buckles), која исто запажа да авантуристичке игре поседују „снажне контемплативне особености“, као и да прелажење авантуристичке игре има сличности са читањем дугачког и сложеног прозног дела (Исто).

Очигледно је, дакле, да је Милорад Павић говорио баш о оним видео-играма које су већ својим типолошким особеностима предодређене да поседују развијене литерарне елементе. Међутим, на овом месту морамо напоменути да, иако су игре авантуристичког/стратегијског типа у време када је Павић писао есеј „Романи без речи“ биле ретки представници медијума видео-игара који су поседовали раз-

7 „Interactive Fiction: The Storygame 'Adventure’“; 1985, University of California at San Diego. 
вијену наративну компоненту, то није случај са данашњом продукцијом видео-игара. Развој технологије омогућио је не само побољшање њиховог графичког изгледа - тродимензионалне игре, рецимо, већ деценијама су стандард у креативној индустрији видео-игара, а не захтевни експерименти као што су били деведесетих - него и развијање сложенијих система игривости. Као што је развој књижевних облика и жанрова (у смислу савремене генологије) довео до појаве хибридних модернистичких облика попут прозаиде, графичке новеле или фиксап романа, прогресија информатичке технологије утицала је на међусобно прожимање Крофордових родова видео-игара. Акционе игре главног тока, попут серијала Call of Duty, данас неретко поседују системе унапређења пасивних вештина преузете од игара играња улога. На другој страни, RPG-ови све чешће добијају елабориране борбене системе који захтевају агилност на џојпеду, уместо потезних обрачуна који су захтевали пре свега тактички и логистички приступ. Додатно, готово сви жанрови и поджанрови видео-игара данас поседују у мањој или већој мери развијену наративну димензију. Нарочито је то видљиво у жанру спортских симулација, дакле жанровима који су традиционално били намењени искључиво међусобној, multiplayer борби између двоје или више играча, а који данас нуде могућност развијених single player искустава. Савремена остварења из FIFA и NBA2k серијала омогућавају играчима да, уместо да управљају тимовима на спортском терену, направе свог „лика“ (фудбалера, односно кошаркаша) којег ће потом водити кроз његову каријеру, обликујући његов пут не само на терену него и посредством дијалога са агентима, саиграчима, тренерима и осталим личностима из приватног живота. Ова појава могла би бити тема засебног истраживања, па ћемо се стога уздржати од даљег развијања ове занимљиве, али за наше проучавање дигресивне теме.

\section{Zork и Павићеве интерактивне приповетке: простор и време у интерактивној фикцији}

Повезаност авантуристичких игара и књижевности је, као што је споменуто, дубока и траје од самих почетака жанра. Још од краја седамдесетих и почетка осамдесетих година 20. века, авантуристичке игре - које су у овом добу махом били деривати игре Adventure (1976), прве у жанру - као наративну позадину за играчево истраживање виртуелног простора узимале су приповедне обрасце жанрова популарне књижевности: епске фантазије, крими приче, авантуристичких повести. Такве приче биле су неупоредиво сложеније у поређењу са било којим другим жанром видео-игара, који углавном нису ни поседовали наративне елементе, изузев чисто концептуалних попут „војник у рату“ или „истраживач у џунгли“. Чак и у овако раној фази развоја неки наслови поседовали су још комплексније особине попут 
различитих дијалошких линија које је играч могао одабрати током комуникације са другим ликовима, односно могућности одабира другачијих завршетака игре у односу на изборе играча/јунака.

Нешто касније, на ограниченом тржишту авантуристичких игара почеле су се појављивати и интерактивне адаптације популарних остварења жанровске фикције попут серијала о Шерлоку Холмсу, Госйоgара йрсииенова и Ауйосйойерскоі воgича кроз їалаксију (Aarseth 1997: 101). Први примерци авантуристичких игара поседовали су све већ описане особености жанра: кретање по отвореном свету, решавање когнитивних препрека попут логичких загонетки или дијалошких опција, а све у сврху откривања заплета, односно решавања централне мистерије у причи. Авантуристичке игре из ове фазе њиховог развоја биле су на још директнији начин повезане са књижевношћу. Ограничене скромним техничким способностима првих рачунара, нарочито услед њихове намере да својим садржајем обухвате читаве књижевне светове и најразличитије могуће начине интеракције, ране авантуристичке игре нису поседовале графички приказ, него се њихов виртуелни свет дочаравао текстом, одакле и назив „текстуалне авантуре“. Такве игре су симулирале усмено, интерактивно приповедање присутно у друштвеним играма играња улога (попут Dungeons and Dragons). У оралном кибертексту, како је овакав тип нарације назвао Арсет (Aarseth 1997: 98), један играч је преузимао улогу приповедача и другим играчима описивао свет којим се крећу. Текстуалне авантуре стога се играчу обраћају у другом лицу, али за разлику од једног сличног књижевног пројекта, романа Ако јеgне зимске ноћи неки йуйник Итала Калвина (чије се година објављивања, 1979, поклапа са рађањем жанра компјутерских авантура, што наводимо само као занимљивост), оне су биле много интерактивније природе, дозвољавајући отворену комуникацију са игром преко тастатуре куцањем кључних речи које денотирају одређену акцију (Use, Examine, Walk, Climb).

Комуникација играча са машином једна је од првих манифестација дигиталног хипертекста у модерној уметности, а жанр текстуалних авантура први је прави пример интерактивне фикције, специфичног књижевног жанра формираног крајем 20. века, којег Милорад Павић у својим текстовима назива различитим именима: хипертекст, нелинеарни наратив, la literature a contrainte (Павић 2005: 15). Враћање у ову, за појам видео-игара, далеку прошлост значајно нам је због успостављања следећих односа. Прво, Милорад Павић је и сам писао дела интерактивне фикције која су прилагођена читању/игрању у дигиталном окружењу (http://www.khazars.com/srYU/interaktivna-dela). Друго, не само да читав жанр авантуристичких видео-игара потиче од текстуалних авантура него је и једна од најстаријих и најутицајнијих текстуалних авантура, Zork (1980), директни претходник једном од „романа без речи“, игри Zork: Nemesis. 
У елементарном смислу, Павићева хипертекстуална проза не разликује се од текстуалних авантура. Сваки књижевни хипертекстуални систем састоји се од међусобно повезаних текстуалних фрагмената, односно „јединица читања“ које је Ролан Барт назвао „лексијама" (lexia; Barthes 2002: 13); термин је у својој хипертекстуалној наратолошкој теорији користио и Џорџ Лендоу, док је Еспен Арсет уместо „лексија“ користио свој термин „текстони“ (texton). Пратећи линкове између различитих лексија, било да су у питању дигитални хиперлинкови или обично окретање страница, играч/ читалац креће се од чворишта до чворишта, образујући на тај начин сопствену мапу читања. Лексије су у Хазарском речнику индивидуалне лексиконске одреднице; у Пределу сликаном чајем, то су поглавља која се заједно уклапају у надструктуру укрштенице; у

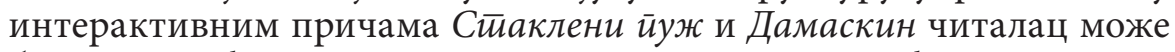
бирати између различитих лексија на тзв. раскршћима, односно „рачвама“ приповетки. Међутим, иако Павићева интерактивна дела садрже исте елементарне честице као и хипертекстуална фикција, сама архитектура његових дела умногоме је различита од уобичајене структуре интерактивне фикције.

Главни елемент сваке видео-игре, од првих остварења попут Spacewara (1962) или Ponga (1972) па до савремених open world авантура, јесте виртуелна презентација простора. Игра, дакле, мора на неки начин приказивати просторни контекст унутар кога hе се одвијати акција или развијати прича, било да је то апстрактно поље Ponga, европска мапа у некој ратној игри или фантазијске локације RPG-a. Исто важи и за текстуалне авантуре које су простор, уместо графички, представљале (односно описивале) вербално. Почетак, односно први екран Zorka играчу тако представља следећу поруку:

You are standing in an open field west of white house, with a boarded front door. There is a small mailbox there.

Текст Zorka није уметнички, него фактографски; његова функција није естетска, нити му је циљ књижевна вредност, већ да играчу представи основне просторне релације како би овај могао да се креће замишљеним светом видео-игре. На почетку Zorka налазимо се на ойвореном пољу, што сигнализира могућност кретања у неколико праваца. Употреба оријентира „западно“ додатно помаже нашем сналажењу у менталној географији, као и спомињање конкретног објекта (поштанског сандучета) са којим нам је, можемо претпоставити, дозвољено да ступамо у интеракцију - поштанско сандуче обично садржи писма, а писма садрже информације. У текстуалним авантурама хипертекстуална структура заправо дочарава нелинеарно кретање кроз простор игре. Прва текстуална авантуристичка игра, чији је првобитни наслов иначе гласио Colossal Cave Adventure, настала је штавише из жеље њеног творца, иначе аматерског спеле- 
олога, да „напише програм који ће симулирати истраживање пећина“ (Aarseth 1997: 99). Поетика сналажења у простору одувек је била уткана не само у текстуалне авантуре, него и у видео-игре уопште. Чак и српски идиомски израз за савладавање игре - „прећи игру“ значењски упућује на савладавање простора (за разлику, рецимо, од еквивалента на енглеском језику: beat the game, победити игру).

Павићева дела интерактивне фикције, међутим, не дочаравају нелинеарно кретање кроз простор као што је то случај са авантуристичким видео-играма. Хипертекстулна архитектура наратива у Павићевом случају пре омогућује нешто што можемо назвати йемйоралном и бокалном нелинеарношћy, то јест слободним кретањем кроз време и различите фокализације наратива. Ала Татаренко је на примеру Хазарскої речника запазила карактеристичност коју можемо сматрати једним од градивних елемената Павићеве поетике уопште: да су његова дела „аисторијска“ у смислу да у њима „нема јасно фиксираних временских граница [...] време је реверзибилно, тече у оба правца“ (Татаренко 2013: 174). Време у делима Милорада Павића често није историјско и каузално, већ митопоетско време у којем не постоје јасне границе између различитих видова прошлости, садашњости и будућности. Сам Хазарски речник, на пример, обухвата неколико векова историје тзв. хазарског питања, а форма лексикона охрабрује читаоца да се том историографијом креће нелинеарно, пратећи не само хронолошки измешане догађаје него и различите перспективе истоветне приче (на пример оне о принцези Атех, која се налази у хипертекстуалним системима сва три дела књиге). У Преgелу сликаном чајем преплићу се, захваљујћи надструктури укрштенице, различите перспективе, генерације и верзије породице Атанасија Свилара/Разина. Унуйрашюа сйрана ветира говори о љубавницима који нису раздвојени само физичким преломом књиге него и временом: Херонеја Букур јунакиња је из савременог доба, а Леандер Чихорић долази из 18. столећа. У краткој причи „Цветна грозница“ долази до стравичног разрешења натприродног укрштања нашег и античког времена; у „Вечери у Крчми код знака питања“ се у сновитој реалности сусрећу живи и преминули пишчеви пријатељи; „Двобој“ прати причу о деветнаестовековном сукобу Лукијана Мушицког и митрополита Стратимировића, који се волшебно прелива у данашње време.

Узмимо, на крају, као примере и интерактивне приче „Стаклени пуж“ и „Дамаскин“. Када се у овим делима понуди избор између две могућности прогресије приче, на такозваним „раскршћима“ или „рачвањима“, читаоцу се сугерише да, уколико није прочитао оба алтернативна поглавља, то учини пре него што настави са читањем остатка приче. Оваква организација текста умногоме се разликује од Арсетовог схватања ергодичке књижевности које налаже да у интерактивном делу постоје „стазе којима се није пошло“ 
(Aarseth 1997: 3), то јест да одабир једних лексија чини неки други скуп лексија недоступним. У Арсетовом виђењу кибертекста, прецизније, неке могућности приче се не остварују науштрб других, у зависности од избора читаоца. У Павићевој организацији хипертекста, међутим, не само да су све лексије увек доступне читаоцу, и да одабир једних не значи неутралисање других, него се читаоцу и експлицитно наређује - као у случају поменутих интерактивних прича - да истражи све могућности лавиринтског текста пре него што настави даље.

Свесна различитих начина организације хипертекстуалног дела, М. Л. Рајан је описала типове текстуалне архитектуре какве може поседовати интерактивно дело, са основном поделом између унутрашње и спољашње интерактивности (internal/external), односно истраживачке и онтолошке (exploratory/ontological) (Ryan 2006: 107). Према таквој типологији, Павићеве приче би припадале истраживачком модусу, односно оном где активност читаоца/играча не мења заплет или свет дела; читалац/играч слободан је да на различите начине истражује простор или нелинеарну причу дела, али без утицаја на судбину тог виртуелног света (Ryan 2006: 108). На другој страни, видео-игре авантуристичког типа примењују онтолошки модус интерактивности, приликом кога акције читаоца/играча диктирају судбину њиховог аватара, његове изборе, и следствено томе, судбину фиктивног света (Ryan 2006: 116).

У случају Павићеве интерактивне фикције нема погрешних или тачних стаза којима се читалац може кретати, нити од распореда читаочевог читања зависи судбина јунака или дела. У поменутим приповеткама „Стаклени пуж“ и „Дамаскин“ - али и у Павићевим романескним делима - алтернативне лексије заузимају исту позицију у просторно-временском континууму приче. Када у приповеци „Стаклени пуж“ дођемо до „средишње копче“, како Павић означава централно, сидрашко поглавље, примећујемо да су се догађаји из обе почетне лексије десили јер су се оба фрагмента одвијала у исто време, али на делимично различитим локацијама и из перспективе различитих ликова. Чак и ауторски коментар на другом „раскршћу“, који раздваја два завршетка приче, такође саветује читаоцу „да се прочитају оба завршетка, јер само у причама могу постојати два различита краја, у животу не“ (Павић 2008: 434). У приповеци „Дамаскин“" на почетку последњих поглавља сазнајемо да су се остварили догађаји из оба претходна „рачвања“: ни палата коју гради Јован Дамаскин ни храм који подже Јован Лествичник нису завршени.

М. Л. Рајан наводи неколико наративних схема интерактивне фикције. Павићеве интерактивне приче у овом случају не спадају у облик „лавиринта“ (maze), који садржи негативне завршетке који означавају неуспех, нити „дрвета“ (tree), где један избор увек неутралише другу опцију напредовања. Интерактивне при- 
че Милорада Павића у извесној мери заузимају форму „мреже“ (network), која дозвољава темпорално нарушавање каузалитета приче, и у којој одлуке читаоца/играча одлучују не шта ће се следеће десити у свету приче, већ којим ће се редом догађаји презентовати (Ryan 2006: 103-106). Можемо додати: како у Павићевим хипертекстуалним делима нема лексија које су погрешне, које изопштавају друге опције, или које представљају fail state, његови хипертекстуални фрагменти заправо постоје на истом месту и у исто време у архитектури приче, те метафорички формирају структуру палимпсеста; парадоксално, лексије у интерактивној прози Милорада Павића постоје једна преко друге.

\section{4. Светови-књиге: виртуелни простори и постмодерна фантастика}

У већ расправљаном чланку Р. Кувера аутор се осврнуо на неколико нових технолошких средстава која су се могла користити за стварање ове неконвенционалне књижевности, спомињући између осталог и HyperCard - софтверски алат који је крајем осамдесетих година развио Епл (Apple) и који је омогућавао да се преко хиперлинкованих „картица“, које су могле садржавати текстуалне и визуалне податке, креирају не само пословне презентације него и дела интерактивне литературе. Остало је забележено да је и Милорад Павић макар једном приликом стварао на сличан начин. Чак и ако по страни оставимо очигледну сличност између мешања картица и тарот романа Послеgна тьубав у Цариіраgу (који је сам парафраза Замка укритенеих суgбина, интерактивног тарот романа Итала Калвина), један његов запис сведочи да је прва рука Хазарскої речника била написана у виду 47 комадића хартије на којима је било написано 47 одредница за поглавља будућег романа (Павић 2005: 14). Павић додаје: „Иако компјутери [тада] још нису били уведени у домове [...] писао сам нешто што ће се показати као веома подесно за коришћење у дигиталном окружењу. Списатеље који се данас баве таквом нелинеарном прозом називају свугде електронским писцима“" (Павић 2005: 14).

HyperCard је, дакле, осим пословне примене био коришћен и за писање интерактивне фикције, најчешће дигиталних верзија такозваних „одабери своју авантуру“ (choose your adventure) дела - обично дечијих или омладинских књига које су у писаној форми симулирале орални кибертекст из друштвених игара играња улога. Помоћу HyperCard-a стварана су и комплекснија остварења, од којих су једна од најзначајнијих два наслова Ренда и Робина Милера (Rand, Robyn Miller): Manhole (1988) и прва верзија Myst-а. Иако Павић у есеју „Романи без речи“ описује пре свега литерарну вредност потоњег дела, оно је у историји видео-игара остао запамћен као револуционарно и 
из технолошких разлога. У време објављивања, Myst je био вероватно најимерзивнији виртуелни свет икада направљен, захваљујући подједнако његовој величини, реалистичном графичком изгледу, као и могућности да се истражује из перспективе првог лица.

Визуелну раскош Myst-a и његовог наставка, Riven-a, регистровао је и Милорад Павић. Уместо ограничених могућности HyperCard-a, браћа Милер су коначну верзију Myst-а изградили помоћу тада најсавременијих алата за 2Д и 3Д моделовање: Stratavisiona 3D, Macromedia Macromodela и Photoshopa. Myst се састојао од преко 2.000 рендерованих слика које су дочаравале фантастичан простор острва Мист и осталих локација којима се у игри могло приступити. Међутим, хипермедијални скелет игре и даље је био изграђен помоћу HyperCard-a, који је, као што је у претходном делу објашњено, био коришћен за дочаравање нелинеарног виртуелног простора видео-игре. Сваки екран је тако био једна „картица“, а кликом на заглавља екрана играч се могао пребацивати на суседну локацију, односно следећи екран, то јест нову лексију. Оригиналне верзије игре су се одвијале попут слајдшоуа - тек је ремастерована верзија игре (RealMyst, 2000) увела анимацију ходања између смене екрана, симулирајући тако кретање играча.

Myst jе на тај начин био једна од првих игара која је помоћу комплексне географије заправо дочаравала метафоричну слику виртуелног простора видео-игре као лавиринта, односно сложеног, нелинеарног простора који се морао покорити, прећи или победити. Неки савременији наслови из поджанра авантуристичких игара из првог лица чак су пружали неку врсту метажанровског коментара на мотив лавиринта: Talos Principle (2014), у којем играч преузима улогу андроида у потрази за Богом-Творцем, одвија се у анахроном амбијенту античких рушевина и рачунарских постаја свесно обликованих у лавиринтске облике; лавиринти су централни мотив, како у спацијалном тако и у смислу игривости логичких загонетки и у уметничко-експерименталном остварењу The Witness (2016).

У формално-технолошком смислу Myst je донео огромну промену у жанр авантуристичких игара. За разлику од Zorka, који је виртуелни свет представљао апстрактно - текстуалним материјалом - и за разлику од осталих остварења у оно време најпопуларнијег авантуристичког жанра, тзв. point and click авантура, чији је графички изглед био близак анимираним филмовима и које су се играле из изометријске перспективе, Myst је карактерисала реалистична графика и играње из првог лица. Један од разлога, уосталом, зашто Милорад Павић издваја своје „романе без речи“ јесте њихова карактеристична визуелна презентација која их је одвајала од карикатуралног приказа „компјутерских игрица“, односно игара које су, попут point and click авантура, поседовале стилизованији визуелни изглед. Реалистична графика Myst-a и осталих романа без речи на- 
глашавала је њене „одрасле“ теме, као што је „дечија“ графика point and click авантура (говоримо овом приликом пре свега о насловима развојних кућа Sierra и LucasArts) потцртавала њихове фарсичне, хумористичне и углавном пародијске наративе.

Раскошни визуелни ресурси „романа без речи“ дозволили су приказивање подједнако детаљних и сложених локација; свакако неупоредиво сложенијих од пећинских ходника Adventurea или Zorka, и простора који су притом видљиво кореспондирали специфичним мотивским елементима Павићеве прозе. Решавајући убиство у Zork: Nemesis-y, играч се креће унутрашњостима музичког конзерваторијума, древног манастира и војничке тврђаве, што у великој мери одговара неким лајтмотивима Павићеве књижевне праксе (музика, архитектура, духовност/хришћанство, ратништво/маскулинитет). Радња ове игре се у једном тренутку трансформише из мистерије убиства у метафизичку љубавну причу о судбином раздвојеним љубавницима, а елементи радње укључују и друге павићевске елементе попут алхемије, хороскопа, врачања, астрологије, метемпсихозе и реинкарнације. Радња игре Timelapse интригантно је слична радњи Хазарскоі речника, као и већ образложеном аисторијском третирању времена. Играч у овом остварењу истражује нестанак Атлантиде, а дешифровање њеног усуда чини направом која му омогућује да путује кроз време. Посећујући три различите епохе - мајанску, египатску и индијанску - играч мора реконструисати улаз у Атлантиду и тиме разрешити енигму њеног нестанка. У питању је, дакле, дословно остварење Павићеве метафоричне надприче о читаоцу, који, истражујући писана предања три религије, односно три цивилизације (хришћанске, исламске, јеврејске), реконструише праву судбину хазарског народа. Timelapse се бави, као и Хазарски речник, проблемима културног памћења, цивилизацијске ентропије и могућношћу реконструкције изгубљене повести помоћу фрагмената и посредних трагова.

Специфичан однос према времену можемо препознати и у чињеници да се унутар измаштаног света Myst-a различити паралелни светови које играч током игре упознаје заправо називају Доба (Ages). Myst и његов наставак, Riven, уз то се служе и одређеним мотивима које можемо описати као типична обележја постмодерне фантастике и, уопште, постмодернистичке прозе. Играч тако у раној фази играња сазнаје да је средишња локација у видео-игри Библиотека на острву Мист, а главни заплет постаје потрага за изгубљеним текстовима како би се помоћу њих реконструисала права истина о судбини играча и других ликова у игри. Библиотека у коју играч залази је руинирана, са свега неколико преживелих примерака књига, од којих неки садрже енциклопедијске уносе о осталим световима доступним о игри. Осим информативне и имерзивне улоге дочаравања веродостојности измаштаног света, ови записи имају и прагма- 
тичну функцију, пошто често садрже имплицитне трагове назнаке о решењима препрека у игри, захтевајући тако од играча способност не само пажљивог, него и креативног читања. Нарочито место у Библиотеци заузимају две оштећене књиге из којих се играчу јављају гласови необичних прилика, који моле да се њихови кодекси обнове сакупљањем страница разасутих по целом виртуелном свету игре. Што више ових страница играч буде сакупио, то ће у све већој мери комуницирати са приликама које су заробљене у књигама. Две тајновите фигуре ће заузврат откривати информације о свету и себи самима; изјаве ових утвара ће на тај начин производити наративну напетост, јер играч све до завршетка игре неће бити у могућности да засигурно утврди која од прилика говори истину, а која не.

Играње семантичким конвенцијама текста, које је код Милорада Павића присутно у бројним примерима фантастичне интертекстуалности, метатекстуалности и хипертекстуалности - као што је присутно и у читавој постмодерној стилистици - чини окосницу лудолошко-наративне структуре Myst-a и Riven-a. Играч ће различите светове у играма посећивати тако што ће дословно урањати у књиге у којима су они описани. По уласку у нови свет, играч ће пред собом имати увек исти краткорочни циљ: повратак на острво Мист тако што ће, на крају света/нивоа, пронаћи књигу по имену „Myst“, која ће му омогућити повратак у овај основни свет видео-игре. Као и у случају игре Timelapse, Милораду Павићу се и ово могло учинити као буквализација једне постмодернистичке идеје, овога пута о мултипликацији стварности, односно о реалности текста као засебној стварности независној од реалног света. Симболичка слика урањања у измаштани свет текста је у Myst-у централни мотив радње и примарни начин интеракције са различитим виртуелним просторима садржаним у игри.

Постојање оваквих магијских књига, које бришу онтолошку границу између текста и правог виртуелног света, објашњено је у сложеној митологији саме видео-игре. Све књиге-светови у свету Myst-a и Riven-a створила је фантастична раса демијурга - којима иначе припадају две прилике заробљене у књигама, као и њихов отац, прави циљ потраге играча - који поседују способност да стварају читаве универзуме писањем текстова. У питању је, дакле, још једна оживљена метафора. Отац Атрус, творац светова, у пренесеном значењу представља архетип аутора: он је творац књига, стога и свих светова кроз које се играч креће; наша потрага у Myst-у заправо је потрага лика за писцем. 


\section{5. Уместо закључка:}

\section{интеракција међу играчима и дружење међу читаоцима}

Наслов овог истраживања, „Шта је играо Павић?“, пре свега је фигуративан. Са сигурношћу не можемо рећи да ли је Павић заиста играо четири игре које је споменуо у есеју „Романи без речи“. Као аутор који је био упознат са савременим феноменима интерактивне фикције, врло је могуће да је поседовао детаљно, али ипак само посредно знање о неким упечатљивијим примерима хипермедијалне књижевности, односно видео-игара. За ово истраживање такви подаци из приватног живота, уосталом, нису ни значајни, будући да нам је циљ пре свега био да осветлимо дубље поетичке и стилско-мотивске разлоге Павићевог одабира баш ових игара (Myst, Myst 2: Riven, Zork: Nemesis, Timelapse) за демонстрирање литерарних домета овог медијума. Чињеница да ли се Павић заиста лично кретао, за тастатуром и мишем, њиховим виртуелним просторима, мање је битна у овој књижевно-научној студији.

Међутим, на крају свог излагања, Павић се осврнуо на једну занимљиву појаву из света видео-игара:

Постоје на Интернету аматерски приручници, које они корисници који су се с успехом пробили кроз неки од ових романа без речи, шаљу онима који нису нашли даљи пут. [...] Понекад се екипе младих људи удружују и заједничким напором наште за једну ноћ успеју да „савладају“ или како се каже „разбију“ игрицу. (Павић 2005: 62)

Милорад Павић овде говори о „водичима“ (walkthroughs), нарочитим текстуалним суплементима који су одувек пратили жанр авантуристичких игара. Како се авантуристичке игре састоје од изазова и препрека чије решење често није очигледно (за разлику од акционих игара), није редак случај да играчима буду потребни месеци, па чак и године како би успешно прешли неку игру. У случају да нису успевали да реше неку загонетку, у помоћ су долазили водичи - углавном анонимни текстови објављивани на сајтовима специјализованим за „шифре“ (cheats) и друге пречице у прелажењу игре, које су писали они играчи који су игре већ успешно савладали. Водичи су у том смислу представљали неку врсту интерпретативних хипертекстова, и то хипертекстова у изворном књижевнотеоријском значењу; секундарних текстова, овом приликом написаних како би се изворни хипотекст - у овом случају видео-игра - лакше схватио, разумео и на крају прешао.

Павићева информисаност о водичима могла је, још једном, бити само посредна. За овај део културе видео-игара могла га је, као постмодерног аутора, заинтересовати њихова природа секундарног текста, који, као што је то случај са хришћанском, исламском и јеврејском верзијом хазарског питања, на посредан начин помажу 
проналажење коначне истине (то јест, разрешења неке игре). Такође, могла га је привући њихова друштвена димензија, односно онај тренутак интеракције између два читаоца/играча, једног ко је у игри застао и другог који ју је „разбио“, и које међусобно спаја само дело које играју, као што двоје читалаца из „Завршне напомене о користи од овог речника“" на крају Хазарскої речника спаја само Павићев роман-лексикон. Са друге стране, Милорад Павић можда је заиста играо све, неке, или само једну од видео-игара које је споменуо, па је због тога био, у неком тренутку, принуђен да се посаветује са неким водичем на интернету - ова упутства за прелажење игре свакако није спомињала ни теоријска литература, ни критички прикази видео-игара у магазинима и на сајтовима. Као што је речено, овај биографски факат није нарочито битан. Ипак, да је Милорад Павић заиста играо видео-игре, то би показало како је он, од прве појаве личних рачунара, све више упознавао могућности и светску продукцију нових приповедних медијума; као и да их је поштовао не само као занимљиве концепте, него као права књижевна дела у којима је лично уживао и налазио уметничку вредност.

\section{ЛИТЕРАТУРА}

Aarseth, Espen. Cybertext: Perspectives on Ergodic Literature. Baltimore: The John Hopkins University Press, 1997.

Barthes, Roland. S/Z. Hoboken: Blackwell Publishing, 2002.

Coover, Robert. „The End of Books“. The New York Times, 21. јун 1992. http://movies2.nytimes.com/books/98/09/27/specials/coover-end.html. Приступљено 17. фебруара 2019.

Crawford, Chris. The Art of Computer Game Design. Pullman: Washington State University, 1997.

Joyce, Michel. „Afternoon“ (одломак), Postmodern American Fiction: A Norton Anthology. New York: W. W. Norton \& Company, 1997.

Павић, Милорад. Роман као gржава и gруїи оїлеgи. Београд: Плато, 2005.

Павић, Милорад. Све ирриче. Београд: Завод за издавање уџбеника, 2008.

Pavić, Milorad. Interaktivna dela. http://www.khazars.com/sr-YU/interaktivna-dela. Приступљено 17. фебруара 2019.

Ryan, Marie-Laure. Avatars of Story. Minneapolis: University of Minnesota Press, 2006.

Татаренко, Ала. Поейика форме у йрози срйской йостимоgернизма. Београд: Службени гласник, 2013.

Tretiak, Phillipe. „Enfin un roman qu'on peut lire dans tous les sens“. Paris Match, 17. март 1988. 
Miloš Jocić

What Did Pavić Play? Ludo-narrative aspects of the adventure game genre, as seen in Milorad Pavić's essay "Novels Without Words".

\section{Summary}

In this paper we will attempt a thorough interpretation of Milorad Pavić's essay "Novels Without Words", which is one of the first attempts at a ludo-narrative interpretation of video games in Serbian literary theory. In this essay, Pavić provided a unique testimony on the contemporary hypermedia and hypertextual literature, the central point of this work being his description of four adventure games: Myst, Myst 2: Riven, Zork: Nemesis and Timelapse. By analyzing the historical development of the adventure game genre, their hypertextual architecture, technological characteristics, and certain elements that link them to the general poetics of postmodern fiction, we will attempt to explain the mechanisms of Pavić's ludo-narrative commentary, i.e. the reasons behind his choice of these particular titles for the purpose of demonstrating the literary and artistic value of video games in general.

With this in mind, the first part of our paper presents a brief summary of the development of the adventure game genre, with special accent on the phenomena of so-called "textual adventures". Here we argue that adventure games, due to the cognitive nature of their interactions and challenges, are inherently suitable to having a developed narrative dimension, which makes the genre open to different kinds of literary influences. This provides an explanation as to why Pavić chose this particular genre as the focal point of his article.

The second part of our examination argues that examples of Pavićs interactive fiction have a structure diametrically different from the hypertextual architecture of video games. While video games usually utilize a hypertextual structure to present, first and foremost, different representations of virtual space, Pavić's interactive fiction has a role of representing temporal and focal nonlinearity.

The third part of our research takes into account different stylistic practices of the aforementioned video games, arguing that Pavić probably chose these particular four titles because of their similarity to his own literary practice. The most important example here is Myst and the different postmodern elements in its ludo-narrative structure, such as motifs of textual meta-reality and the demiurgical nature of the author.

The final part of this research presents arguments which substantiate a theory that Pavić actually did play the games he mentioned, and wasn't just indirectly informed about them. The main argument is the fact that Pavic knew about the existence of the so-called "walkthroughs", the supplementary, secondary texts used by players to easily navigate through the game and beat it. While acknowledging that the biographical fact concerning whether Pavić played the games or not is of no particular importance to this research, his direct involvement with this medium will show how much Milorad Pavić, in fact, followed contemporary trends in the hypertextual and hypermedia art.

Keywords: Milorad Pavić, interactive fiction, video games, lexia, hypertext 